\title{
REESCRIBIR EN FEMENINO. LA REELABORACIÓN DEL MITO ARTÚRICO EN LAS NIEBLAS DE AVALÓN DE MARION ZIMMER BRADLEY
}

\author{
YolANDA BETETA MARTín \\ Universidad Complutense de Madrid \\ yolandabeteta@hotmail.es
}

\section{RESUMEN}

El objetivo del artículo es analizar el papel de los mitos en la construcción de la subjetividad femenina. La construcción de nuevas identidades, a través de la subversión de los mitos, decodifica el imaginario simbólico androcéntrico para crear nuevos modelos de feminidad. La reescritura del mito artúrico muestra el poder de la literatura para desnaturalizar mitos ancestrales profundamente resistentes a las nuevas identidades del siglo XXI.

PALABRAS ClAVE: Mito; reescritura; identidad femenina; posmodernismo; literatura feminista.

\section{ABSTRACT}

The aim of this essay is to analyze the role of myths in the construction of female subjectivity. The construction of new identities by means of the subversion of myths, decodes their symbolic male-centred imagery in order to create new icons of femininity. The rewriting of the Arthurian myth shows the capacity of literature to denaturalize ancestral myths profoundly resistant to the new identities of the 21 st century.

KEYWORDS: Myth, rewriting, female identity, postmodernism, feminist literature. 
La literatura y el mito han desempeñado un papel fundamental en la configuración del universo simbólico y de la construcción cultural de las categorías de género que han condicionado nuestra percepción del mundo. Bajo esta lógica, sería imposible concebir la historia de las mujeres sin una historia de sus representaciones, de sus mitos y de la decodificación de sus imágenes, pues son aspectos que expresan la construcción y evolución del imaginario social femenino y de toda la estructura social que lo acepta, lo conforma y lo reproduce.

El mito es una realidad extremadamente compleja que podría abordarse e interpretarse de diferentes maneras a menudo complementarias. En este ensayo abordaré su estudio desde una perspectiva de género que arroje luz sobre su incidencia en la configuración del ideal de la feminidad y en su evolución bajo las nuevas identidades femeninas construidas al compás de los cambios sociales.

Un breve recorrido histórico por el mito artúrico nos permite comprobar el modo en que las representaciones de las mujeres, siempre de autoría masculina y subordinadas al canon androcéntrico, se han convertido en iconos culturales que han perpetuado unos roles de género profundamente jerárquicos. El mito ha constituido una representación simbólica de las identidades de género, de modo que el cambio en los roles de género de las mujeres requiere forzosamente un cambio en el orden simbólico. Esto ha implicado la deconstrucción y reelaboración de estos arquetipos y la creación de imágenes alternativas más acordes con las nuevas identidades femeninas.

El análisis de los mitos y su reelaboración en las obras literarias es fundamental a la hora de diseccionar el universo simbólico de las sociedades creadoras/receptoras de los mitos. Las narraciones míticas son representaciones simbólicas de la realidad que trascienden a su tiempo y proyectan unos valores determinados que son asimilados por la cultura a través de sucesivos procesos de aculturación. La existencia del mito se expresa como respuesta a una necesidad existencial y un acontecer inherente al imaginario colectivo de las sociedades y los modos de representación de la realidad. Como afirma Malinowski (1995: 101).

El mito no es una explicación destinada a satisfacer una curiosidad científica sino un relato que hace vivir una realidad original y que responde a una profunda necesidad religiosa, a aspiraciones morales, a coacciones, a imperativos de orden social e incluso a exigencias prácticas.

El mito se sitúa por encima del tiempo histórico. Surge en el imaginario colectivo y forma parte de una estructura simbólica permanente que se refiere simultáneamente al pasado, al presente y al futuro (LEVI STRAUSS 1973: 189) Es esa universalidad y sentido trascendente lo que reconocemos en los mitos artúricos. El universo dramático compilado y reelaborado por Thomas Malory en «La muerte de Arturo» forma parte del imaginario colectivo que encarna las aspiraciones, deseos, dudas, conflictos, relaciones y pasiones basados en los ideales de justicia y lealtad. Es la poetización de una realidad sórdida que necesita ser embellecida a través del mito. Por este motivo, el mito puede ser considerado como la primera expresión artística del ser humano que se ha perpetuado a través de la palabra y de la escritura. La incorporación de los mitos al imaginario colectivo impregna con su simbolismo las creencias y tradiciones culturales de las sociedades crea- 
doras/receptoras de los mismos. El simbolismo y su carácter ahistórico y diacrónico los convierten en una fuente constante de inspiración para la literatura. La literatura rescata las narraciones míticas para profundizar en su esencia y significado y para reelaborarlas de acuerdo a las nuevas necesidades históricas (HERRERO 2006: 59).

El mito se perfila como una realidad presente que convive en las sociedades contemporáneas debido a que algunos de sus aspectos y funciones responden a aspiraciones e incertidumbres que son inherentes al ser humano y que afloran permanentemente formando parte de una cosmovisión. Como señala Elíade, las sociedades utilizan el mito como técnica para percibir lo eterno y renovarse. Gracias al mito, las ideas de realidad, valor y trascendencia se abren paso lentamente (ELÍADE 1996: 27).La relación entre el mito y la literatura tiene un carácter bidireccional. Las reelaboraciones literarias convierten las narraciones originales en «mitos literaturizados» convirtiendo la mitología en materia literaria (SIGANOS 1993: 32). La literatura, que tradicionalmente se ha inspirado en los mitos, se convierte en mito al reelaborar las narraciones e incorporarlas al universo de símbolos y mitos que nutre nuestro imaginario cultural (GARCÍA BERRIO 2004: 472). La vigencia de los mitos clásicos en la sociedad actual evidencia que las narraciones pueden ser reelaboradas de acuerdo con las necesidades del siglo XXI y con la redefinición de nuevas identidades de género. Por lo tanto la reelaboración del mito artúrico que realiza Marion Zimmer Bradley debe ser entendida como una revisión de la tradición artúrica que se adecua a las exigencias de la actual sociedad del logos en la que las mujeres han socavado los tradicionales roles de género impuestos por la estructura patriarcal.

El mito femenino que formaba parte de la tradición artúrica - Ginebra, Morgana e Isolda - satisfacía las necesidades androcéntricas de una sociedad medieval caracterizada por una sólida jerarquía de género en la que las mujeres ocupaban un lugar subordinado frente a la hegemonía masculina. Pero las identidades representadas por estos personajes ya no son viables una sociedad en la que las mujeres están desbordando las tradicionaless fronteras de género. Para ahondar en la relación existente entre mitos e identidades femeninas es necesario entender la preeminencia de la autoría masculina en la producción de capital simbólico y los modelos de feminidad que propone el mito artúrico. Porque ¿qué sería de Odiseo sin Penélope? ¿De Perseo sin Medusa? ¿De Arturo sin Ginebra? ¿De Jasón sin Medea? ¿De Adán sin Eva? Las mujeres han ocupado un lugar central en la configuración de los mitos aunque no como sujetos sino como objetos sociales. Las mujeres quedaron excluidas de la producción de los mitos y su presencia en el mundo mítico se reduce a perpetuar el capital simbólico en dos niveles complementarios: naturalizando la ideología inherente a los mitos - las mujeres socializan a las niñas y niños en la normativa patriarcal - y formando parte de los relatos míticos como idealizaciones sobre las que reposan los estereotipos «femeninos» que responden a las necesidades de la estructura patriarcal.

La negación de la autoría femenina y la exclusión de las mujeres de la cultura, entendida como ausencia en la creación de capital simbólico, priva a las mujeres de su consideración como sujetos sociales. Recluidas en la esfera doméstica, excluidas de la Historia y dibujadas como objetos fértiles que reproducen el linaje y el imaginario simbólico, las mujeres se erigen como las depositarias de un entramado cultural que inmoviliza su libertad cognitiva, emocional y sexual. La autonomía de las mujeres se diluye, además, por 
efecto de lo que Foucault denomina la «microfísica del poder», esto es, la dominación invisible que se instala inconscientemente sobre la conciencia para conseguir «cuerpos dóciles», objetos transmisores de un sistema cultural pretendidamente natural (FOUCAULT 1998: 185).Las mujeres quedan inmovilizadas en los mitos como objetos simbólicos y personajes arquetípicos para codificar un pensamiento androcéntrico que las invisibiliza en una espiral de relaciones basadas en el dominio y la subordinación. Un breve recorrido histórico por los mitos permite comprobar el modo en que las representaciones de las mujeres las han convertido en iconos culturales que han perpetuado las relaciones jerárquicas de género y han modelado las categorías de lo masculino y lo femenino.

La cultura occidental está repleta de imágenes, arquetipos y modelos procedentes de narraciones mitológicas que asocian la violencia, la fortaleza y la actividad como señas de masculinidad y la maternidad y sexualidad como rasgos esenciales de las mujeres. La violencia simbólica, seña de identidad que define la categoría de lo masculino, constituye la base de las relaciones sociales y de género y está presente en todas las historias mitológicas: desde aquellas que ahondan en la búsqueda de un pasado heroico sobre el que fundamentar el origen de un pueblo, por ejemplo, la fundación de Roma, hasta las que rescatan la hipotética descendencia de un linaje real a partir de un antepasado mitológico como la simbólica vinculación entre los reyes micénicos y los héroes homéricos, pasando por aquellas narraciones que recrean vivencias de héroes, como en la tradición homérica, o reyes legendarios, como en las leyendas artúricas.

Los mitos recrean e idealizan algunos de los rasgos definitorios de las sociedades patriarcales para naturalizar y legitimar una cultura normativa tendente a perpetuar la dicotomía masculino-femenino en términos de dialéctica hegeliana. Las capacidades reproductivas de las mujeres y la necesidad de controlar su sexualidad aíslan a las mujeres en un espacio físico y simbólico que condiciona su desarrollo individual. Históricamente las mujeres se han visto socialmente limitadas a desempeñar el rol de esposa y madre en un espacio vital reducido al espacio doméstico. Esta percepción social de las mujeres se extrapola al mundo de los mitos donde aparecen relegadas a objetos pasivos, simples receptoras del deseo sexual de unos dioses que inscriben la violencia patriarcal en cada uno de sus actos. Dafne, Aretusa, Filomena, Medea o Cenis padecen la violencia masculina como la aceptación de una actitud inherente a los dioses en su calidad de varones que exhiben su masculinidad. Las mujeres, como seres pasivos, no tienen valor socialmente y quedan relegadas a una simple propiedad cuya única función social es la reproducción y perpetuación del linaje.

La influencia del orden simbólico sobre el que se articulan los modelos de identidad social, al tiempo que perfila nuestras experiencias, tiende a penalizar las conductas que no corresponden a los roles de género preestablecidos en la imaginería colectiva. En este sentido, es interesante señalar cómo la mitología clásica, el imaginario religioso medieval, la literatura victoriana y, más recientemente, el cine han extrapolado el perfil de las mujeres sexualmente activas y sin hijos a una iconografía negativa basada en el modelo estereotipado de la «femme fatale» y la mujer vampira, esta última inspirada en la imagen mitológica de la Lilith babilónica. La iconografía de un mujer sexualmente activa, lésbica y carente de «instinto maternal» representaba a un tiempo los temores de un sociedad patriarcal que históricamente abogaba por el sometimiento y refinamiento de las 
mujeres. Las fantasías y los mitos cosifican a las mujeres en unas categorías de género profundamente jerárquicas al relegar la imagen de la mujer independiente y activa al mundo simbólico de las fantasías penalizando su reproducción social.

Los mitos, al tiempo que rechazan la actividad sexual femenina desligada de la reproducción biológica, refuerzan la construcción sociocultural de la heterosexualidad como marco normativo sobre el que se asienta la estructura patriarcal. La necesidad de controlar la sexualidad femenina responde a varios factores, principalmente la certeza de la paternidad y la transmisión de la propiedad por vía patrilineal, pero todos derivan de la consideración de la mujer como un valioso bien material. Lévi Strauss aseguraba que la prohibición del incesto y el consiguiente intercambio de mujeres entre diversos grupos familiares permite la creación de alianzas intergrupales que incrementan las posibilidades de supervivencia y el estatus de los grupos sociales. En este sentido, las mujeres se convierten en objetos de transacción de incalculable valor por lo que el sistema patriarcal sanciona todas aquellas conductas que obstaculizan el reparto intergrupal de las mujeres (STRAUSS 1983: 135).

Autoras como Jacqueline Zita (1981:172) y Adrienne Rich (1980: 631) conceptualizan el control social de la sexualidad femenina bajo el término «heterosexualidad obligatoria», entendida como una condición universal para la mujer vinculada con el patriarcado que perpetúa la dominación masculina. Aunque la mayoría de los estudios antropológicos rechazan el concepto de «heterosexualidad obligatoria» porque proporciona una visión limitada de la sexualidad femenina, lo cierto es que la heterosexualidad se erige como modelo y engranaje básico de la familia, el parentesco y la sexualidad en la mayor parte de las culturas. Históricamente, pese al reconocimiento institucionalizado del matrimonio entre mujeres en ciertas regiones muy concretas de África, fundamentalmente Lesotho y Mombasa, el reconocimiento de las relaciones entre mujeres en la hermandades chinas o la homosexualidad masculina ritualizada entre los sambia de Nueva Guinea, la identidad sexual se forja a partir de unas representaciones simbólicas de marcado carácter heterosexual.

Los mitos se nutren de símbolos universalmente aceptados que naturalizan ontológicamente a las mujeres como cuerpos sexuados vinculados a la fecundidad y sexualidad. Desde las manifestaciones artísticas paleolíticas en forma de vulvas que dibujadas en las zonas más inaccesibles de las cuevas hasta la ingente variedad de pequeñas figuras que representan a diosas femeninas presentes en a mayoría de las sociedades humanas, se ha consolidado la imagen de la mujer como ser poderoso y a la vez temido, creadora de vida y al mismo tiempo potencial castradora de la masculinidad, expresada en la fantasía de la vagina dentata, que ha configurado el imaginario simbólico de las sociedades patriarcales en dos modelos dicotómicos y asimétricos.

El mito de la vagina dentata ha sufrido continuos procesos de reelaboración. Junto a la relación simbólica que el discurso patriarcal ha establecido entre la sexualidad de las mujeres y el «monstruo femenino» - gorgonas, arpías, quimeras, sirenas, etc. - , el falocentrismo ha trazado una línea invisible que une la sexualidad femenina con los comportamientos «castradores» de hembras de distintas especies que culminan la cópula con la muerte del macho. Las imágenes de la mantis religiosa o de la araña tejedora orb se han esgrimido como una evidencia de la capacidad sexualmente devoradora de la hembra de la especie, afianzando la naturalización de atributos impuestos por la cultura. Las ana- 
logías que la estructura patriarcal ha establecido entre las estrategias reproductivas de estas especies y la capacidad «devoradora» de las mujeres responden a una construcción sociocultural que intenta «biologizar la cultura». Y podemos dar la vuelta al discurso biológico afirmando que las diferentes estrategias reproductivas y sociales presentes en el reino animal nos muestran que el patriarcado, como condición social humana vinculada al control de la reproducción de las mujeres, no es inevitable, por ejemplo, las hembras de los primates lémures mantienen el control de sus grupos sociales.

La pervivencia de los postulados platónicos y aristotélicos en las sociedades occidentales ha perpetuado una imaginería simbólica plagada de mitos, símbolos y fantasías que, debidamente actualizada conforme a las necesidades históricas, tiene su origen en la tradición mitológica grecorromana. Uno de los textos que recoge las tradiciones mitológicas más conocidas de la cultura occidental es las Metamorfosis de Ovidio. La obra consta de un conjunto de relatos mitológicos de los que más de cincuenta recogen pasajes de agresión sexual contra mujeres. Los estudios decimonónicos sobre literatura ovidiana no sólo han obviado este hecho sino que han intentado eludir el término «violación» empleando eufemismos como «seducción»o «cortejo» (RICHLIN 1992: 214).

Uno de los mitos que recoge la esencia del discurso patriarcal con mayor nitidez es la historia de Medusa y Perseo; mito que Freud interpretó desde una perspectiva psicoanalítica como el temor a la castración masculina. El mito hereda la tradición oriental al recuperar la imagen del ser femenino de apariencia monstruosa que es vencido por el héroe mitológico valedor del sistema patriarcal. Medusa, al igual que las arpías, sirenas, quimeras, hidras y gorgonas que pueblan el imaginario grecorromano clásico, representa el desdoblamiento demoníaco del «otro» femenino en una imaginería en la que «el héroe varón no sólo debe medirse con sus iguales antagónicos sino que también debe enfrentarse a sus opuestos inferiores»(CASANOVA y LARUMBE 2005: 188). La conversión de Medusa en un ser monstruoso se concibe como un castigo por la violación que padece a manos de Poseidón. De este modo el mito contribuye a afianzar el rol de las mujeres como símbolos sexuales que incitan a la sexualidad masculina. Medusa recibe la culpa de su propia violación y en ella recae el castigo normativo en forma de deformidad física y de transformación de sus cabellos, construidos literariamente como amenaza sexual, en serpientes.

La presencia de las serpientes es una constante en la imaginería androcéntrica y su evolución es una muestra de las reelaboraciones patriarcales de los mitos femeninos. Las culturas orientales establecieron una asociación simbólica de la categoría de lo femenino con la capacidad regenerativa de la serpiente que algunos autores enmarcan dentro de una red más amplia de simbolismo lunar (ELÍADE 2005: 163). La desautorización de la serpiente como símbolo femenino se inicia en Occidente con su representación como encarnación del diablo y culmina con la iconografía barroca de la Virgen aplastando la cabeza del ofidio. María, máximo exponente del concepto cristiano de mujer, se erige como la nueva Eva que aplasta el legado diabólico y pecaminoso de la Eva edénica. Esta desautorización de la serpiente como símbolo de fertilidad se une al discurso androcéntrico que deslegitima el valor de las mujeres y su impronta en el capital social y simbólico.

Medusa es la representación del «monstruo femenino» por excelencia. Los monstruos son simples manifestaciones de los dos temores primordiales del ser humano, la 
muerte - Tánatos - y el sexo - Eros - , y el monstruo femenino va a constituir la encarnación de esos miedos primordiales en una sociedad patriarcal (KAPPLER 1980: 274) En un sistema androcéntrico en el que las estructuras patriarcales deben velar por la trascendencia de la «primacía del falo», los miedos sólo pueden encaminarse en una dirección: el temor a lo femenino. La necesidad de controlar la sexualidad de las mujeres responde al miedo a la naturaleza femenina y su «capacidad de castración» de la masculinidad. Es muy significativo que sea una figura femenina, la diosa Atenea, quien castiga a Medusa y la convierte en un ser monstruoso. Pero un análisis más detallado de la figura de Atenea muestra que la diosa no era considerada como una mujer desde un punto de vista androcéntrico ya que no aparece investida de las cualidades femeninas por excelencia; no es esposa ni madre. Frente a una Atenea virgen y representada con atributos «masculinos» como el yelmo y la lanza a modo de una «virgo bellatrix», Medusa se erige como un modelo de feminidad. Atenea se alía con la causa de la sociedad patriarcal al instigar la muerte de Medusa y alentar al héroe androcéntrico encarnado en Perseo. Atenea es la mujer que refrenda los valores patriarcales adoptando el rostro femenino de la masculinidad. El mito confronta, así, dos modelos opuestos de feminidad: la voluptuosidad de Medusa y el carácter asexual de Atenea.

Mención destacada merece la interpretación freudiana de la decapitación de Medusa a manos de Perseo. Freud, en el ensayo La cabeza de Medusa, establece una relación simbólica entre la cabeza decapitada de Medusa y la vagina materna. De acuerdo con Freud, la visión de la cabeza de Medusa provoca un terror similar al que experimenta un niño al contemplar los genitales de la madre. Medusa es una proyección simbólica del terror masculino hacia lo femenino y lo materno, hacia lo deseable y lo aterrador, hacia la seducción y la sexualidad castradora (FREUD 1979: 270).

Las implicaciones represivas del mito son evidentes y es recurrente la representación de las mujeres como «castradoras de masculinidad» a lo largo de la Historia bajo diferentes nombres femeninos: Lilith, Judith, Salomé, Jezabel, Dalila o Morgana entre otras (WARNER 1987). Los mitos femeninos simbolizan el precio de la transgresión femenina ante los dictados de las leyes patriarcales. El reconocimiento de las mujeres como sujetos sociales únicamente procede del grado de identificación con la autoridad dominante.

El miedo masculino a la «castración» sitúa los mitos femeninos como un referente simbólico que refuerza el aislamiento de las mujeres en el espacio del mithos. El mito de la Eva bíblica es especialmente revelador del temor masculino que despierta la capacidad de la autoría femenina, de la producción de capital simbólico y del uso de la palabra. El castigo de Eva es una respuesta patriarcal al deseo de sabiduría femenina representada por el árbol del bien y del mal. Y su transgresión no puede ser más reveladora del carácter sexual al que quedan reducidas las mujeres en el mundo simbólico: Eva es condenada a parir con dolor, a la sumisión y a la dependencia masculina. Este mito fundante incapacita a las mujeres para acceder al logos y las diluye en un imaginario colectivo profundamente discriminatorio con pretensión de inmortalidad (DE LA CONCHA 2004).

Uno de los mitos más extendidos en la literatura occidental es el mito artúrico. Desde las crónicas de Geoffrey de Monmouth se han producido constantes reelaboraciones de la mano de autores como Chretien de Troyes, Thomas Malory, Spencer, Milton, Alfred Tennynson, Harold White, John Steinbeck, Mark Twain y Marion Zimmer Bradley, entre otros. En ellas observamos cómo el mito se depura y reestructura para acomo- 
darse a los nuevos tiempos históricos conservando intactos los valores arquetípicos que definen a los héroes y heroínas, tales como el valor, la integridad, el sacrificio y, especialmente en el caso de las mujeres, la sumisión y la seducción. El mito literario artúrico se remonta al siglo XII pero el núcleo de la tradición artúrica moderna se condensa en La muerte de Arturo de Thomas Malory publicada en 1485. Se trata de una síntesis de la leyenda artúrica bretona que compila y reelabora las diversas versiones dotándolas de una sólida estructura interna. La obra se erige como una idealización de un pasado histórico que ha sucumbido ante las luchas dinásticas de la Guerra de las Dos Rosas, el desmantelamiento de las lealtades feudales, la disolución de los ideales del amor cortés y la progresiva decadencia de la clase nobiliaria. La muerte de Arturo surge como un canto de cisne a una Inglaterra mítica que se convierte en el referente colectivo de una sociedad en proceso de cambio.

La finalidad primaria del mito es configurar un modelo de sociedad e individualidad androcéntricas que, bajo el perfil del rey-guerrero, personifica un modelo idílico de comportamiento y de masculinidad. Arturo se convierte en el arquetipo del noble feudal que guía el destino de su pueblo con justicia y concordia entre sus caballeros. El mito adquiere así un valor afectivo que contribuye a forjar la identificación social con el héroe mítico y sus valores universales, de tal modo que el mito primario se halla mucho más arraigado que cualquier reelaboración posterior. El mito artúrico nos ofrece la imagen de una sociedad mítica articulada sobre unas relaciones feudales de carácter patriarcal. El sesgo androcéntrico es especialmente visible en la estructuración de la sociedad en fatrías configuradas en torno a grupos masculinos de pares en los que no tienen cabida las mujeres. De hecho, la irrupción de las mujeres en el sistema masculino origina la disolución del mismo. El ciclo artúrico nos ofrece un modelo arquetípico de masculinidad basado en la violencia contra los enemigos y la lealtad entre los caballeros. Como señala Eva Keuls, la manipulación de las narraciones mitológicas puede llegar a legitimar actitudes extremadamente violentas naturalizando el «falicismo» entendido como la combinación de supremacía masculina, culto al poder androcéntrico y violencia como valor supremo de la masculinidad (KEULS 1993: 98).

Las leyendas artúricas aglutinan una serie de narraciones de origen céltico que recrean, en cierta medida, algunos de los rasgos definitorios de las sociedades medievales pero también de las sociedades actuales. Acercarse a la literatura épica medieval es vislumbrar, desde un primer momento, un problema de género no sólo literario sino principalmente un problema de imagen genérica sexual. Escindida, fragmentada y contradictoria, la imagen femenina se vio condicionada por el discurso clerical, es decir, el discurso masculino de quienes detentaban el poder de la palabra, de la cultura y de la tradición. Impuro por esencia, el género femenino durante el medioevo no tuvo oportunidad de reconocerse como un auténtico otro; siempre, en diferentes grados según regiones y épocas, dependió del universo masculino para justificar su existencia. Agrupadas por su género, no existían diferencias determinantes entre unas y otras para el universo masculino; todas llevaban la maldición de Eva o encarnaban la idealización de la Virgen María. Sin embargo, los ciclos artúricos rompen con la tradición literaria que sitúa a ambos sexos en espacios sociales antagónicos. La literatura épica en la que se encuadran las obras artúricas es un género masculino por excelencia que incluye la-formación y vivencias del rey-guerrero y de la fatría como arquetipo de masculinidad por lo que no 
debe extrañar que los protagonistas sean hombres. Pero las mujeres son imprescindibles ya que a través de ellas el héroe inicia o trasmite su linaje - Igraine-, obtiene el poder de la guerra - la Dama del Lago - y se redime a través del amor - Ginebra - . Siguiendo el modelo genérico de la literatura épica, el ciclo artúrico realza los personajes femeninos dotándolos de un mayor peso específico en la narración. Exalta el arquetipo femenino derivado del romance y la tradición del amor cortés ofreciendo una imagen extremadamente polarizada de las mujeres en dos modelos antagónicos: Morgana y Ginebra, reminiscencias de la mencionada dicotomía Eva-María, aunque la redención final de Morgana al recoger el cuerpo de Arturo en Avalón y la relación adúltera de Ginebra introduzcan una ruptura significativa.

La novela de caballería impulsó un imaginario colectivo en el que las mujeres, fundamentalmente las pertenecientes al estamento nobiliario, se convirtieron en un objeto de culto que exaltaba sus perfecciones morales y estéticas. Bajo la falsa idolatría a la mujer, se perpetúa su sumisión y pasividad. Es depositaria de los afectos y servicios del caballero pero su margen de acción no va más allá de ser una fuente de inspiración. Reproduce el rol de musa, capaz de inspirar las más nobles acciones de los caballeros pero continúa recluida en la esfera doméstica sin capacidad de decisión. Así, las vidas de Morgana, Ginebra e Igraine están determinadas por las decisiones que los hombres han adoptado sobre ellas. Son inspiradoras pero no creadoras ni dueñas de su propia vida. Y aquellos personajes femeninos que rompen con la imagen androcéntrica de las mujeres quedan convertidos en imagen antagónica de la «buena dama».

A lo largo del siglo XX la situación de las mujeres en Occidente fue experimentando una transformación progresiva que fue redefiniendo las tradicionales identidades de género. La sociedad que se está gestando ya no debe ser replanteada en términos de «masculinización y feminización» porque los límites de las identidades de género se han desdibujado al compás de la entrada de las mujeres en ámbitos tradicionalmente masculinos. Las mujeres han comenzado a desplegar una identidad individual independiente que ha sobrepasado los antiguos límites de las identidades androcéntricas que dificultaban el desarrollo de la individualidad femenina (HERNANDO 2008: 64). Este desarrollo está cuestionando la tradicional complementariedad de sexos, la heterosexualidad obligatoria y los roles de género. Los tres conceptos se sitúan en la base del poder patriarcal y el primer paso para desmontar la estructura falocéntrica es socavar sus cimientos pero no estamos cerca del fin del patriarcado. Las mujeres deben iniciar un proceso de reestructuración del universo simbólico que se adapte a las nuevas identidades que se están desarrollando en las últimas décadas y que permita transformar la realidad tangible.

Roland Barthes puso de relieve una visión semiótica de los mitos que sienta las bases de las posteriores revisiones feministas al considerar que «el mito constituye un sistema de comunicación, un mensaje. Esto indica que el mito no podría ser un objeto, un concepto o una idea; se trata de una significación, de una forma» (BARTHES, 1997: 199). La perspectiva semiótica de Barthes subraya que los mitos no son inmutables y que son susceptibles de ser sometidos a procesos de desestructuración y decodificación que socaven «el principio mismo del mito, transformar la historia en naturaleza» (BARTHES 1997: 222). En consecuencia, Barthes propone una transformación de los mitos que desnaturalice las construcciones socioculturales de las identidades históricas. 
Los procesos de deconstrucción de los mitos a través de las revisiones literarias se erigen como estrategias de cambio que permite decodificar los mitos androcéntricos y construir imágenes alternativas de feminidad. Autoras como Mary Daly, en su obra Gyn/Ecology. The Metaethics of Radical Feminisms, ya respaldaron en la década de los setenta las revisiones de los mitos patriarcales como instrumento para decodificar la cultura y la literatura. Pero será en la década de los ochenta cuando la subversión de los mitos androcéntricos experimente un impulso teórico definitivo de la mano de autoras como Alice Ostriker y Marina Warner. La crítica norteamericana Alice Ostriker crea el concepto «revisionist mythmaking» (OSTRIKER 1986: 316) -creación revisionista de los mitos - como una estrategia feminista para deconstruir los mitos y reestructurar un lenguaje patriarcal sobre el que reconstruir un nuevo universo simbólico que no denigre la representación simbólica de las mujeres. Sobre esta base teórica y metodológica se erige uno de los estudios más fascinantes sobre la iconografía femenina, Monuments and Maidens. The Allegory of the Female Form, de Marina Warner, que explora la naturalización de los arquetipos culturales de feminidad y alienta la desarticulación de los mitos falocéntricos. Warner insiste en que la subversión no radica en la creación de nuevos mitos que carecerían de inmortalidad - rasgo inherente al mito - sino en reescribir los clásicos mediante una subversión discursiva que evidencie su carácter mutable, contrariamente a la inmortalidad que les ha sido atribuida.

Las escritoras contemporáneas reivindican un papel activo y crítico en la producción de capital simbólico que nos permita reencontrarnos a nosotras mismas en la cultura más allá de unos modelos identitarios sesgados, manipulados y mutilados. Reclaman una labor de deconstrucción que impida que las mujeres de generaciones futuras sientan la misma frustración que expresaba Hélène Cixous: «...me busco a través de los siglos y no me veo en ninguna parte» (CIXOUS 1995: 31).

Las revisiones literarias de los mitos dotan de voz a los personajes femeninos que quedaron silenciados bajo el yugo simbólico y social de un sistema patriarcal que invisibilizaba la individualidad femenina bajo la categoría artificial y homogénea de «feminidad». Una feminidad construida en virtud de necesidades y fantasías masculinas. Por ejemplo, conocemos el mito troyano a través de las voces de los héroes homéricos, las calamidades del regreso de los héroes a Ítaca desde la perspectiva de Odiseo. Nos sumergimos en el reino de Camelot y la búsqueda del Grial bajo la percepción de los caballeros de la corte artúrica y nos adentramos en la historia de Medea bajo el prisma de Jasón. Pero ¿qué tendrían que decir los personajes femeninos de los mitos si les cediéramos la voz narrativa? La subversión de los mitos que llevan a cabo las escritoras concienciadas de su poder de articulación de identidades y significaciones nos permite adentrarnos en un mundo mitológico en el que las mujeres alzan la voz en una Ítaca androcéntrica para denunciar la discriminación sufrida en su propio hogar.

En esta línea revisionista, Marion Zimmer Bradley reescribe el mito artúrico en la novela Las nieblas de Avalón (1979) situando a Morgana como la narradora de un relato que tradicionalmente la había condenado al ostracismo, la hechicería y el oscurantismo. Los mitos comienzan a ser analizados como construcciones temporales y, por tanto, contingentes. Bradley en Las nieblas de Avalón establece un diálogo con la narración original (hipotexto) para reformularlo y establecer con él una relación de hipertextualidad. Bradley nos muestra el mito artúrico desde el punto de vista de los personajes femeninos. 
Morgana se erige como la narradora del relato y a través de sus ojos vivimos una renovación del mito que deconstruye y reelabora la narración ancestral y su supuesta intemporalidad. La reescritura es explícita y está señalada tanto por el nombre de los personajes como por el marco histórico y temporal en el que se inscribe su acción. Sin embargo, el significado de las actuaciones y las características que definen a los personajes son reorientados por la autora en correspondencia con un mensaje metafórico que privilegia los sentimientos, las vivencias y las necesidades vitales de unos personajes femeninos que habían sido silenciados en el mito original.

El prólogo de Las nieblas de Avalón ya anuncia la nueva perspectiva:

Habla Morgana. En mi vida me han llamado de mucha maneras: hermana, amante, sacerdotisa, hechicera, reina. Ahora, ciertamente soy hechicera, y acaso haya llegado el momento de que estas cosas se conozcan (...) Pero ésta es mi verdad; yo, Morgana, os la cuento. Morgana, la que en épocas más actuales se llamó Hada Morgana ( BRADLEY 2000: 9-11).

El juego intertextual entre el hipotexto y el hipertexto obedece a una estrategia que rescata a los personajes marginales de la narración original para ofrecer la perspectiva «femenina». El eterno conflicto entre los bretones y los sajones que, en la narración de Malory es un recurso narrativo que conlleva la exaltación de los valores arquetípicos del rey-guerrero, se reconfigura en Las nieblas de Avalón bajo la rivalidad entre el cristianismo y un paganismo vinculado al culto a la Diosa Madre. Marion Zimmer Bradley replantea el nudo argumental para situarlo en una esfera simbólica en la que el culto a la Diosa Madre cede terreno a una religión de marcado carácter patriarcal. En este sentido, el simbolismo de Las nieblas de Avalón requiere un análisis detallado.

Las mujeres de Avalón que nos muestra Bradley son adoradoras de la Diosa Madre, conocedoras de los misterios telúricos y custodias del culto lunar, como evidencian los tatuajes lunares que adornan sus rostros cuando son investidas como sacerdotisas de Avalón. Estos rasgos actualizan la histórica relación simbólica que se ha establecido entre las mujeres y la naturaleza. La imagen de la luna como un símbolo de fertilidad aparece en numerosas culturas mediterráneas. Las culturas orientales establecieron una asociación simbólica de la categoría de lo femenino con la capacidad regenerativa de la luna, que algunos autores enmarcan dentro de una red más general de simbolismo femenino (ELÍADE 2005:163). Esta relación intrínseca entre los ciclos lunares y la fertilidad de la tierra - y por extensión la fertilidad femenina - puede ser encuadrada en un proceso cultural de sacralización de la naturaleza que ensalza la capacidad engendradora y dadora de vida de la Diosa Madre. En la novela de Marion Zimmer Bradley, las sacerdotisas de Avalón se erigen como el alter ego del Merlín artúrico. Merlín adquiere una posición secundaria en Las nieblas de Avalón y sus capacidades proféticas y protectoras recaen en la Dama del Lago y Morgana. Ambos personajes adquieren una mayor relevancia en la narración de Bradley y están dotados de una necesidad y una experiencia vital propias. Tienen un presente y un pasado y luchan por forjarse un futuro frente al avance de un sistema patriarcal representado por la expansión del cristianismo frente a los cultos paganos. Unos cultos de marcado carácter sexual - cultos de Beltane - que no podrían tener cabida en la obra de Thomas Malory. Así, en Las nieblas de Avalón las mujeres evidencian una relación natural con su propia sexualidad y su vida. El personaje de Morgana se despoja del 
halo maléfico que la caracterizaba en La muerte de Arturo y se erige como una mujer fuerte y temperamental que renuncia al destino que la Dama del Lago había marcado para ella, aunque finalmente retorne a Avalón ante la descomposición del reino artúrico. Por su parte, Ginebra, que en la obra de Malory quedaba oscurecida por las figuras de Arturo y Lanzarote sin posibilidad de desarrollar una identidad propia, emerge como una mujer que se debate entre la fidelidad a sus creencias religiosas cristianas y la fascinación de las artes mágicas de Avalón que podrían devolverle la fertilidad.

Ambos personajes son más complejos que los perfiles mostrados por Malory, y los restantes personajes femeninos que se deslizan en la trama - Igraine, Viviane, Morgawse, Eliane, etc - enriquecen el mito al mostrarnos una perspectiva de la historia inédita hasta el momento. Especialmente interesante es la relación incestuosa que surge entre Morgana y Arturo bajo el simbolismo de los rituales de Beltane. El incesto no es un elemento narrativo exclusivo del mito artúrico sino que presenta una larga trayectoria en la narrativa medieval. Un sector importante de la crítica literaria ha mantenido que las historias de incesto medievales se derivan directa o indirectamente del mito de Edipo. Pero para Otto Rank, las leyendas medievales del incesto difieren de los mitos clásicos, y las fantasías incestuosas que se complacen en acercar al ser humano hasta los límites morales sólo pueden concebirse como una respuesta al alto grado grado de represión de la sociedad cristiana medieval (RANK 1991: 271). Más recientemente, Elizabeth Archibald, más allá del debate acerca de sus orígenes literarios, afirma que una de las innovaciones literarias de los autores medievales fue precisamente el tema del doble incesto (ARCHIBALD 2001). La obra de Malory recoge una relación incestuosa entre Arturo y Morgawse (hermanos maternos) mientras que Bradley focaliza el incesto en una relación fortuita que mantienen Arturo y Morgana. Las consecuencias narrativas de ambas relaciones son similares: el nacimiento de Modred y la caída del reino artúrico. Pero el halo pagano que envuelve los rituales de Beltane reorienta el sentido de la relación incestuosa.

En Las nieblas de Avalón Viviana se erige como el reverso femenino de Merlín y dirige los destinos de los personajes artúricos para perpetuar el legado de la Diosa. En este caso, la relación de incesto no se diluye bajo el ritmo narrativo impuesto por las aventuras de los caballeros de la corte, como sucede en la obra de Malory, sino que adquiere un protagonismo esencial en el que de nuevo el simbolismo adquiere una importancia vital: la imagen del ciervo, símbolo cristiano de espiritualidad adquiere un nuevo significado en Las nieblas de Avalón al ser la imagen que caracteriza a Arturo investido como «machorey» en los ritos de Belthane. Marion Zimmer Bradley transforma el simbolismo cristiano del ciervo en La muerte de Arturo para situarlo al servicio de la visión pagana y feminista de Las nieblas de Avalon cuya crítica al carácter androcéntrico del mito queda encarnado en las sacerdotisas de Avalón.

Llegados a este punto, cabe preguntarse si Las nieblas de Avalon contribuye a desnaturalizar el mito androcéntrico y situar a las mujeres en una nueva esfera simbólica que replantee sus necesidades vitales y, lamentablemente, hay que decir que, pese a la tendencia claramente feminista que muestra la autora al ceder el protagonismo a los personajes femeninos, la obra perpetúa una visión esencialista de las mujeres que actualiza la ancestral vinculación simbólica entre feminidad y naturaleza. Avalón constituye el único reducto en el que las mujeres gozan de libertad y autonomía pero no puede considerarse 
como un centro de empoderamiento femenino porque su poder reside exclusivamente en el conocimiento de los misterios de la naturaleza. Fuera de Avalón la influencia de las mujeres es extremadamente limitada. El poder femenino queda enclaustrado y su posible influencia fuera de la isla es invisibilizada por el reconocimiento social de los druidas que, pese a enarbolar un conocimiento similar al de las sacerdotisas de Avalón, sí gozan de prestigio en la esfera pública de Britania. El poder político de Camelot únicamente reconoce a los hombres como interlocutores válidos en los asuntos públicos. En un contexto dominado por la pugna simbólica entre el cristianismo y el paganismo los hombres se erigen como los valedores de dos sistemas antagónicos: los sacerdotes lideran el avance de una religión cristiana que excluye a las mujeres de la vida pública siguiendo el discurso patrístico y los druidas enarbolan la bandera de un paganismo que intenta sobrevivir en medio de luchas fatricidas entre las tribus de Britania.

Pese a que la novela insiste reiteradamente en la visibilidad que ostentan las mujeres en el paganismo, las sacerdotisas de Avalón tienen escasa influencia en los asuntos políticos de Britania y son los druidas encabezados por Merlín quienes gozan de los favores de la corte. Las sacerdotisas intervienen en la política de Britania de manera velada debiendo recurrir a las artes mágicas para cambiar el destino del país. El poder de las mujeres queda arrinconado en la isla de Avalon tras las nieblas que separan física y simbólicamente el mundo de la magia del mundo real. Un aislamiento que posteriormente padecerán las mujeres tras la imposición del cristianismo. La nueva religión recluye a las mujeres en la esfera doméstica e imposibilita su acceso al conocimiento alegando razones biológicas o naturales. En este contexto de subordinación, las mujeres ven en los conventos una vía de libertad que les permite vivir de espaldas a la autoridad patriarcal. En este sentido se puede trazar una línea de continuidad entre la isla de Avalón y los conventos cristianos como reductos de libertad femenina, si bien limitada.

Un estudio superficial de la vida conventual haría suponer que los conventos eran lugares enclaustrados y aislados del mundo exterior. Pero el estudio de las fuentes históricas muestra que las órdenes religiosas se convirtieron en importantes centros de cultura donde las mujeres podían acceder a unos conocimientos que les eran vetados fuera de los muros conventuales. Los conventos a su vez permitían el acceso y alojamiento de mujeres que, por diferentes motivaciones, permanecían temporalmente en ellos sin llegar a tomar los hábitos. Y de la misma manera, las mujeres religiosas gozaban de visibilidad social más allá del espacio conventual, como muestra la presencia de beatas y místicas en los círculos cortesanos. Un ejemplo paradigmático de la visibilidad de las mujeres más allá de la reclusión monacal fue Constanza de Castilla, priora del convento de Santo Domingo el Real de Madrid que, en virtud de su parentesco con el rey Pedro I, estableció una red de influencia que se extendía por todos los órganos de poder político, social y eclesiástico. Junto a la vida monacal, la proyección pública de las beguinas y beatas, que por su condición de mujeres, solteras y laicas desafiaban la tradicional jerarquía eclesiástica, y la influencia de las místicas, cuyas revelaciones cuestionaban la incapacidad femenina de interpretar las Sagradas Escrituras, difundieron nuevas formas de religiosidad en las que las mujeres adoptan un papel activo al margen de los cánones androcéntricos. El desafío femenino a las normativas canónicas evidenció la iniciativa de las mujeres y su capacidad para reivindicar una forma de vivir y sentir la religión alejada de la tradicional misoginia patrística. 
Las políticas reformistas de la Baja Edad Media desdibujaron la religiosidad de las beguinas y beatas al integrarlas en órdenes religiosas y obstaculizaron el desarrollo de los monasterios de mujeres como centros de cultura abiertos a la sociedad. Al mismo tiempo, la imposición de la clausura como nuevo precepto ligado a la religiosidad femenina exacerbó la desconfianza masculina acerca de las actividades de las mujeres en el interior de los conventos. Esta desconfianza se sitúa en la base de las muchas críticas androcéntricas que interpretan la clausura como un precepto que, aunque encorseta la libertad de las beguinas y beatas y delimita su visibilidad pública, ofrece una vía de desarrollo femenino que, tras los muros conventuales, permite adoptar una vida heterodoxa en la que dar rienda a los pecados inherentes a la naturaleza femenina. Es el temor a lo desconocido, a lo que «ocultan» los muros de los conventos, el miedo al poder «castrador» de las mujeres lo que emerge tras las críticas contra las nuevas formas de religiosidad femenina en la Baja Edad Media.

La imagen que Marion Zimmer Bradley ofrece de la religiosidad pagana en Avalón sigue la misma trayectoria que la deslegitimación histórica de la religiosidad femenina en la Edad Media. El paganismo y su exaltación de la naturaleza femenina queda relegada al mundo de lo «invisible» tras las brumas de Avalón ante el avance del cristianismo. El carácter falocéntrico de la nueva religión desvirtúa la sabiduría pagana e inicia un proceso de desprestigio que deslegitima las capacidades mágicas de las sacerdotisas de Avalón. La isla se convierte en el último reducto en el que las mujeres pueden enriquecer sus conocimientos sobre los misterios telúricos y adorar a las divinidades femeninas. Avalón se convierte en un centro de poder femenino acosado por el empuje patriarcal del cristianismo.

Comprendí que era uno de esos momentos en que cambia la historia de la humanidad. Los cristianos pretenden borrar toda sabiduría que no sea la suya, y en ese empeño están haciendo desaparecer todo misterio que no concuerde con su fe religiosa (...) Como niegan el mundo del espíritu y los reinos de Avalón, estos reinos dejan de existir para ellos. Existen, por su supuesto, pero no en el mismo mundo que los seguidores de Cristo (BRADLEY 2000: 23).

Una de las razones de la deslegitimación del poder femenino de Avalón radica en la propia concepción cristiana de las mujeres. La figura de Eva está presente en la percepción androcéntrica de la naturaleza femenina y se sitúa en la base de las críticas contra la magia de Avalón. La representación de las mujeres como portadoras del mal se afianza con el cristianismo aunque su origen se remonta a la tradición hebraica que, a su vez, será ampliada con el bestiario griego y su imagen del «monstruo femenino». La sombra de Lilith, Eva y Pandora está presente en el mito artúrico y Bradley esgrime esta imagen denigratoria de las mujeres para dibujar las razones de la oposición del cristianismo a los cultos paganos: «Creen que no hay ninguna Diosa, pues dicen que el principio de la mujer es el principio de todo mal. A través de la mujer, dicen, entró el Mal en este mundo. Los judíos tienen una leyenda sobre una manzana y una serpiente» (BRADLEY, 2000:22).

Una de las líneas argumentales que propone la autora es el enfrentamiento entre el cristianismo y el paganismo pero la pugna entre ambos posicionamientos ideológicos no está lo suficientemente desarrollada. La novela establece una asimilación entre el cristianismo y el patriarcado y entre el paganismo y el matriarcado pero no insiste en las ra- 
zones que desembocan en este enfrentamiento. Algunos fragmentos, como el seleccionado anteriormente, apuntan que el origen del enfrentamiento puede hallarse en el poder que las mujeres ostentaban en Avalón y que podría trasladarse al ámbito político de Britania en un contexto político altamente inestable. La lectura de la novela insta al lector a plantearse si el enfrentamiento ideológico entre paganismo y cristianismo no es tanto una guerra de religiones cuanto una guerra de sexos: la supremacía masculina de Camelot frente a la supremacía femenina de Avalón. Sin embargo, Marion Zimmer Bradley no entra en esta cuestión y la pugna entre ambos modelos de poder se diluye en el relato de la decadencia de Avalón. El cristianismo aparece vinculado a valores masculinos como la venganza y la supremacía androcéntrica frente a un paganismo que apuesta por una relación simbiótica entre las mujeres y la naturaleza. La autora insiste de manera recurrente en la vinculación entre las mujeres y la naturaleza y perpetúa un esencialismo que no contribuye a romper los prejuicios androcéntricos sobre las mujeres. La percepción de las mujeres que propone se acerca a las tesis de Lévy-Strauss acerca de la dicotomía naturaleza/cultura. Mientras que los hombres son sujetos activos en la esfera pública, las mujeres son instrumentos de intercambio que permiten el establecimiento de alianzas políticas que forjan el paso del estado de la naturaleza al estado de la cultura.

Con ello se perpetúa la idea patriarcal de que las mujeres no son creadoras de una cultura socialmente aceptada. Los personajes femeninos dominan los efectos y estados de la naturaleza - la magia y la hechicería - pero no muestran una actitud activa en la producción de una cultura institucionalmente aceptada. En la Edad Media el patriarcado masculiniza la cultura discriminando aquel conocimiento empírico que tradicionalmente recaía en las mujeres. El conocimiento de las plantas medicinales, el cuidado de los enfermos, la manipulación de alimentos, etc., no sólo no son considerados como sabiduría sino que pasan a ser designados como «cultura femenina o popular». Marion Zimmer Bradley no rompe el estereotipo medieval de las mujeres en tanto que no perfila ningún personaje femenino que muestre un conocimiento socialmente reconocido. Las sacerdotisas de Avalón exclusivamente evidencian conocimientos derivados de la magia y hechicería tradicionalmente asociados a lo femenino.

Al mismo tiempo, las mujeres que forman parte de la corte únicamente desempeñan actividades «mujeriles» tales como el hilado, la rueca, la cocina, el cuidado de los niños etc. Los ejemplos se suceden a lo largo de toda la novela. «Hilaba con aire ausente» (17), «Conozco a las señoras Flavila y Gwyneth. Dejan todo en manos de sus maridos, salvo lo referente a la rueca, los partos y otros asuntos de mujeres» (54), «No soy un hombre pobre; puedes comprar sin consultarme lo que necesites para mantener decorosamente la casa» (58).

La libertad y autonomía de las sacerdotisas de Avalón es limitada porque está supeditada a las necesidades políticas de Britania, unas necesidades que responden a los intereses políticos y que, por tanto, tienen un carácter falocéntrico. Las mujeres sacrifican su vida en pos de los intereses masculinos por lo que no existe una diferencia sustancial entre las sacerdotisas de Avalón y las mujeres que viven en la corte de Camelot, siempre supeditadas a intereses más allá de sus propias necesidades vitales. Igraine debe sacrificar su libertad para contraer matrimonio con Uther Pendragón y engendrar el hijo que unificará Britania, mientras que Morgana, sacerdotisa de Avalón, se ve obligada a engrendrar un hijo con Arturo a instancias de la Dama del Lago. En ambos casos, la liber- 
tad de Igraine y Morgana se diluye bajo los intereses políticos de la corte. La aparente libertad de que gozan las sacerdotisas de Avalón es un simple espejismo al servicio de Britania y de los hombres que la gobiernan. Las mujeres no forman parte de ninguna estructura de poder quedando excluidas de cualquier asunto público. «¿Qué puede importarle a una mujer quien gobierne?» (37) Su objetivo vital, incluidas las sacerdotisas de Avalón, es engendrar hijos que perpetúen el linaje y, por tanto, el apellido masculino. Las sacerdotisas de Avalón subrayan, incluso, la representación de las mujeres como instrumentos reproductores del linaje masculino al utilizar la fecundidad femenina al servicio del interés patriarcal (la obligación de Igraine de concebir un hijo con Uther Pendragón a instancias de Viviana) Las mujeres, en suma, independientemente de su procedencia o estatus social, se perfilan como un instrumento político en un complejo sistema de alianzas pactado entre hombres:

Y no había tenido elección. Una hija de la Isla Sagrada tenía que hacer lo que fuera mejor para su pueblo; ya fuera entregar la vida en sacrificio, ya renunciar a su virginidad en el sagrado matrimonio, ya casarse convenientemente para cimentar alianzas (BRADLEY, 2000:16).

La autora pretende establecer una dicotomía Avalón-matriarcado/Camelot-patriarcado que no es viable en tanto que los intereses de las sacerdotisas de Avalón están subordinados a las necesidades de una Britania gobernada por y para los hombres. La revisión del mito artúrico, de este modo, lejos de procurar una visión feminista del mismo, ofrece una visión esencialista de las mujeres que recupera los arquetipos androcéntricos tradicionales y subraya la idea de un matriarcado ancestral previo a la institucionalización del patriarcado. La isla de Avalón se erige como una representación simbólica de un matriarcado primigenio en la línea de las tesis evolucionistas de Bachofen. Las sacerdotisas tejen una estructura de parentesco basada en la matrilinealidad y en un complejo sistema ideológico de oposición masculino-femenino. Las mujeres permanecen asociadas a la luna, la noche, la oscuridad y la naturaleza, lo que impide un cambio discursivo en la evolución del mito, por lo que, en definitiva, la novela ensalza un esencialismo muy cuestionado hoy en día.

La reescritura crítica de Marion Zimmer Bradley nos presenta una nueva perspectiva del mito que, sin renunciar a su naturaleza mítica, delimita su ámbito de aplicación explorando su carácter «local»y «cultural», es decir, su carácter temporal y contingente. El microrrelato ofrece una nueva verdad que cuestiona el mensaje del metarrelato, pero, aún así, no lo adapta al nuevo discurso social. Ciertamente, el cuestionamiento del carácter atemporal de los mitos permite su reestructuración ya que no podemos considerar que los microrrelatos vehiculen la esencia de una verdad objetiva e imparcial. El devenir histórico transforma nuestra percepción del mundo y el desarrollo de las identidades individuales conlleva la emergencia de múltiples verdades subjetivas. Cuestionando el carácter atemporal de los mitos, el mundo artúrico puede ser reelaborado bajo el prisma de las nuevas identidades femeninas que están marcando el proceso de cambio de las sociedades contemporáneas. El mito se transforma, se actualiza y se cuestiona así mismo en un proceso de reescritura que rescata a los personajes silenciados del mito ancestral: las mujeres. Los personajes femeninos dejan de ser puntos de apoyo narrativos que enriquecían una visión exclusivamente patriarcal para erigirse como mujeres con unas vivencias 
propias más allá de los personajes masculinos a los que tradicionalmente estaban referidos.

Como señala Barthes, la transformación de los mitos se erige como un paso necesario para la desnaturalización de las construcciones históricas de la identidad. Sólo el análisis crítico de los mitos permite romper la inercia androcéntrica que perpetúa y refuerza la invisibilidad de las mujeres. Sin embargo, aunque la intencionalidad de Marion Zimmer Bradley es subvertir el mito reescribiendo la narración original desde un punto de vista femenino, la obra acaba perpetuando una visión esencialista de la feminidad que no supone una ruptura significativa del mito primario. De la misma manera que el mito medieval no supone una ruptura con la tradición épica anterior porque el amor cortés enlaza subrepticiamente con la misoginia patrística, la novela de Bradley tampoco supone una transformación de las representaciones clásicas de las mujeres ni una ruptura más allá de un apunte superficial porque no contribuye a que las mujeres puedan reconocerse como sujetos activos y autónomos más allá de los condicionantes impuestos por los roles de género.

\section{BIBLIOGRAFÍA}

Alvar, Carlos (1991): El Rey Arturo y su mundo. Diccionario de mitología artúrica. Madrid: Alianza Editorial.

ARCHIBALD, Elizabeth (2001): Incest and the Medieval Imagination. Oxford: Oxford University Press.

BARTHES, Roland (1997): Mitologías. Buenos Aires: Siglo XXI.

BouRdieu, Pierre (2005): La dominación masculina. Barcelona: Anagrama.

BradLey Zimmer, Marion (2000): Las nieblas de Avalón. Barcelona: Salamandra.

CASAnova, Edualdo y Larumbe, M. ${ }^{a}$ Ángeles (2005): La serpiente vencida. Sobre los orígenes de la misoginia en lo sobrenatural.Zaragoza: Prensas Universitarias de Zaragoza.

CAMPBell, Joseph (1958): El héroe de las mil caras. Psicoanálisis del mito. México: Fondo de Cultura Económica.

Cixous, Hélène (1995): La risa de la medusa. Barcelona: Anthropos.

DAVIES, Lennard (1987): Resisting Novels, Ideology and Fiction,. Londres: Methuen.

De la ConchA, Ángeles (2000): «Los discursos culturales y la constitución de la feminidad». Mercedes Bengoechea y Marisol Morales (coords.). Mosaicos y taraceas: desconstrucción feminista de los discursos del género. Alcalá de Henares: Servicio de Publicaciones de la Universidad de Alcalá, pp 21-36.

- (2007): «Cultura y violencia de género. Literatura y mito en la génesis de un conflicto secular». Circunstancia: revista de ciencias sociales del Instituto Universitario de Investigación Ortega y Gasset, $\mathrm{n}^{\circ} 12$.

- (2008): «El cuerpo como encrucijada de discursos sobre la identidad femenina», Carmen López, y Beatriz Penas (coords.), Paradojas de la interculturalidad: filosofía, lenguaje y discurso. Madrid: Biblioteca Nueva, pp. 163-182.

DURAND, Gilbert (1993): De la mitocrítica al mitoanálisis. Barcelona: Anthropos.

ElíADE, Mircea (2005): Tratado de historia de las religiones. Madrid: Alianza Editorial.

GARCÍA BERRIO, Antonio (1994): Teoría de la literatura. Madrid: Cátedra.

García, Carlos (1983): Historia del Rey Arturo y de los nobles y errantes caballeros de la Tabla Redonda. Madrid: Alianza Editorial. 
Foucault, Michel (1998): Vigilar y castigar. Madrid: Siglo XXI.

FREUD, Sigmund (1979): «La cabeza de Medusa», Más allá del principio del placer, Psicología de las masas y Análisis del yo. Buenos Aires: Amorrortu.

GILBERT, Sandra y GUBAR, Susan (1998): La loca del desván: la escritora y la imaginación literaria del siglo XIX. Madrid: Cátedra, Colección Feminismos.

Grosz, Elizabeth (1991): Jacques Lacan. A Feminist Introduction, Londres, Routledge.

HERNANDO, Almudena (2009): «Género y sexo. Mujeres, identidad y modernidad». Claves de razón práctica $\mathrm{n}^{\circ} 188$, pp. 64-71.

HERRERo, Juan (2006): «El mito como intertexto: la reescritura de los mitos en la literatura». Çédille, Revista de Estudios Franceses $\mathrm{n}^{\circ}$ 2, pp. 58.76.

Herrero, Juan y Morales, Monserrat (2008): Reescrituras de los mitos en la literatura. Cuenca: Ediciones de la Universidad de Castilla la Mancha.

JunG, Carl Gustav (1995): El hombre y sus símbolos. Barcelona: Paidós.

KLAPPER, Claude (1980): Monstruos, demonios y maravillas a fines de la Edad Media. Madrid: Akal.

LeVi Strauss, Claude (1973): Antropología Estructural. Buenos Aires: Universitaria.

- (1983): Las estructuras elementales de parentesco. México: Paidós.

MaLinowsKi, Bronislav (1955): Magic, Science and Religion. Nueva York: Doubleday Anchor Books.

MALORY, Thomas (1985): La muerte de Arturo. Madrid: Siruela.

Keuls, Eva (1993): El reinado del falo: política sexual en la antigua Atenas. Berkeley: University of California Press.

OstriKer, A (1986): «The Thieves of Language. Woman Poets and Revisionist Mythmaking», Coming to Ligth: American Women Poets in the Twentieth Century, en Diane Wood Middlebrook y Marilyn Yalom, Michigan: University of Michigan Press, pp. 225.

PINTOS, Luz (2003): «Cuerpo de mujer y violencia simbólica: una realidad universal», Jacinto Rivera y Carmen López (coords.): El cuerpo. Perspectivas filosóficas. Madrid: UNED, Colección Estudios de la UNED, pp. 291-318.

RANK, Otto (1991): The Incest Theme in Literature and Legend. Baltimore: Johns Hopkins University Press.

Rich, Adrienne (1980): «Compulsory Heterosexuality and Lesbian Existence», Signs 5 (4), pp. 631660.

Richlin (1992): «Reading Ovid’s Rapes», Pornography and Representation in Greece and Rome: Oxford: Oxford University Press, pp. 158-179.

SARTRE, Jean Paul (1989): El ser y la nada. Madrid: Alianza Editorial.

Siganos, André (1993). Le Minotaure et son mythe, París. Presses Universitaires de France.

WARNER, Marina (1987): Monuments and Maidens. The Allegory of the Female Form. London: Picador.

ZITA, Jacqueline (1981): «Historical Amnesia and the Lesbian Continuum», Signs: Journal of Women in Culture and Society, 7 (1), pp. 172-187. 